\title{
Pendidikan, Pembaruan, dan Transformasi: Praktik Pendidikan Islam di Indonesia
}

\author{
Undangan Menulis dan Partisipasi
}

Simposium Nasional Pendidikan Islam

"Pembaruan Pendidikan Islam di Indonesia"

Banjarmasin, 26 s.d. 29 Desember 2019

Southeast Asia Academic Mobility

Majelis Sinergi Kalam Ikatan Cendekiawan Muslim Se-Indonesia

Ismail Suardi Wekke*, Ani Cahyadi**

*Sekolah Tinggi Agama Islam Negeri (STAIN) Sorong, Papua Barat

Email: ismail@stain-sorong.ac.id

**Universitas Islam Negeri Antasari, Banjarmasin, Kalimantan Selatan

Email: anicahyadi@uin-antasari.ac.id

\section{Pengantar}

Abuddin Nata (2019) menerbitkan buku yang berada di publik Maret lalu. "Pembaruan Pendidikan Islam di Indonesia" menjadi judul yang mewakili pembahasan buku. Jikalau Steebrink (1986) mengemukakan perkembangan pendidikan Islam di kurun modern. Maka, dengan hadirnya karya Abuddin Nata menjadi kelengkapan maklumat pendidikan Islam di Indonesia yang mengalami pembaruan dan juga transformasi setelah tujuh dekade kemerdekaan. Temuan dan pembahasan buku tersebut masih merupakan "gambar besar" kondisi pendidikan Islam di Indonesia.

Sementara itu, Indonesia yang terbentang dari Merauke ke Sabang, jika menggunakan kriteria matahari terbit, pendidikan Islam menjadi keperluan masyarakat. Di pulau Sumatera terdapat Lembaga Pendidikan Islam yang tertua di Indonesia (Akhiruddin K, 2016). Di tanah Jawa berdiri berbagai Lembaga Pendidikan Islam, yang cikal bakal muncul Pondok Pesantren (Drajat, M.; 2018). Di tanah Borneo berdiri berbagai Lembaga Pendidikan Islam, salah satunya yang tertua adalah Lembaga Pendidikan Islam Pondok Pesantren Darussalam, yang juga tersedia SMK (Yusliani Noor \& Rabini Sayyidati; 2018). Bahkan di masyarakat Papua, pendidikan Islam yang dikelola YAPIS (Ismail \& Thomas, 2018; Ismail \& Siswandani, 2018) dan juga Muhammadiyah (Wekke, Arif, Zubair, \& Wardi, 2019), tidak hanya dinikmati oleh masyarakat muslim saja. Begitu pula dengan pendidikan Islam yang sudah mengakar dan menjadi lembaga dengan tradisi yang mapan (Wekke \& Busri, 2011; Wekke \& Busri, 2016).

Padahal bentangan pendidikan Islam menjadi bagian dari dinamika kebangsaan. Bali (Wekke, 2016), Manado (Wekke, Yandra, \& Hamuddin, 2017), dua diantara wilayah dimana Islam berjumpa dengan masyarakat dengan keyakinan yang berbeda. Walaupun demikian, pendidikan Islam tetap tumbuh dan juga berkembang. Terlebih lagi di wilayah masyarakat muslim.

Di samping tradisi lisan (Duija I; 2015), tradisi menulis juga merupakan salah satu tradisi yang sudah lama di kembangkan oleh para cendekiawan Indonesia pada masanya (Bruinessen 
M.; 2015). Tradisi ini yang secara terus menerus di kembangkan generasi selanjutnya, untuk pengembangan peradaban dan masa depan tradisi ilmiah umat Islam di Indonesia.

Berdasarkan uraian tersebut, maka dipandang perlu untuk menginisiasi wadah bagi perjumpaan ide sehingga penelitian-penelitian yang sudah ada selama ini akan terpublikasi. Paling tidak, tersimpan dalam repository sehingga dapat diakses oleh publik. Kegiatan diprakarsai Southeast Asia Academic Mobility (SEAAM) dengan laman web www.seaam.net dan Majelis Sinergi Kalam Ikatan Cendekiawan Muslim Se-Indonesia (MASIKA ICMI) dalam program Akademi Tunas Cendekia www.tunascendekia.id

\section{Target Kegiatan}

Simposium yang dirangkaian dengan Writing Camp akan menjadi wahana menulis bersama dengan para pakar, praktisi, peneliti, dan dosen untuk membangun jaringan. Luaran kegiatan antara lain:

1. Artikel di jurnal nasional;

2. Buku edited volume yang akan tersedia di Google Books;

3. Artikel di jurnal internasional bereputasi;

\section{Apa Langkah Selanjutnya?}

SEAAM dan MASIKA ICMI menginisiasi Simposium Nasional Pendidikan Islam yang akan diadakan di Banjarmasin 26 s.d. 29 Desember 2019. Selama kegiatan, peserta diminta untuk berada di tempat kegiatan sehingga sepenuhnya dapat berdialog dengan para mitra bestari dalam memperbaiki naskah yang sementara disiapkan. Adapun jadwal acara sebagai berikut:

\begin{tabular}{|c|c|c|}
\hline Hari \& Tanggal & Program & Acara \\
\hline Kamis, 26 Desember 2019 & Kedatangan & 19.00 - 21.00 Welcome Dinner \\
\hline \multirow[t]{4}{*}{ Jumat, 27 Desember 2019} & $\begin{array}{l}\text { Pembukaan dan Kuliah } \\
\text { Umum }\end{array}$ & 09.00 - 12.00 Diskusi Panel \\
\hline & & $12.00-13.30$ Istirahat \\
\hline & & $13.30-15.00$ Orientasi Program \\
\hline & & $15.00-22.00$ Writing Camp \\
\hline Sabtu, 28 Desember 2019 & Writing Camp & \\
\hline \multirow[t]{3}{*}{ Ahad, 29 Desember 2019} & Writing Camp & $09.00-18.00$ Penyiapan naskah \\
\hline & & $18.00-19.00$ Pengumpulan file \\
\hline & & $19.00-21.00$ Makan malam \\
\hline
\end{tabular}

\section{Pendaftaran}

Peserta dan partisipasi dapat menghubungi Dr. Ani Cahyadi melalui surat eletronik anicahyadi at uin-antasari dot ac dot id. Setiap peserta diharapkan menyiapkan manuskrip sesuai dengan luaran kegiatan yang diharapkan.

\section{Penutup}

Kegiatan ini merupakan kegiatan swadaya, peserta diharapkan mendapatkan dukungan pendanaan dari penelitian atau lembaga masing-masing. SEAAM dan MASIKA ICMI akan memberikan kesempatan untuk mempertemukan para peneliti sehingga akan wujud publikasi bersama dengan kolaborasi diantara para para peserta. 


\section{Daftar Pustaka}

Akhiruddin K. (2015). Lembaga Pendidikan Islam di Nusantara, Jurnal TARBIYA 1(1), 195-219

Bruinessen M. (2015). In the Tradition or Outside? Reflections on Teachers and Influences. AlJami'ah: Journal of Islamic Studies. 53(1) 53

Drajat, M. (2018). Sejarah Madrasah di Indonesia, al-Afkar, Journal for Islamic Studies http://alafkar.com, Vol. 1, No.1, January 2018 E-ISSN :2614-4905, P-ISSN :2614-4883

Duija I, (2015). Tradisi lisan, naskah, dan sejarah Sebuah catatan politik kebudayaan. Wacana, Journal of the Humanities of Indonesia, 7(2) 115

Ismail, R. H., \& Thomas, R. (2018). Building the Civilization in the Perspectives of Islam in Jayawijaya Regency, Papua, Indonesia: The Development of Islam in the Aspect of Human Resources. HONAI, 1(1).

Ismail, R., \& Siswandani, E. D. (2018). The Learning Concept of the Higher Education Students in the Central Mountainous Region of Papua, Indonesia: A Case Study of Students at the STISIP Amal Ilmiah YAPIS Wamena. HONAI, 1(2).

Nata, A. (2019). Pembaruan Pendidikan Islam di Indonesia. Jakarta: Kencana.

Noor, Y., \& Sayyidati, R. (2018). Peranan Tuan Guru Haji Muhammad Kasyful Anwar dan Tuan Haji Setta Dalam Mendirikan Pesantren Darussalam Martapura, Kabupaten Banjar, Kalimantan Selatan, 1924, JUSPI: Jurnal Sejarah Peradaban Islam. Vol. 2 No. 22018 ISSN 2580-8311.

Steenbrink, K. A. (1986). Pesantren, madrasah, sekolah: pendidikan Islam dalam kurun moderen. Lembaga Penelitian, Pendidikan dan Penerangan Ekonomi dan Sosial. Jakarta: LP3ES.

Wekke, I. S. (2016). Learning and Service Quality in Islamic Higher Education of Minority Muslim Bali. International Conference on Ethics in Governance (ICONEG 2016). Atlantis Press.

Wekke, I. S., \& Busri, M. (2011). Pembaruan Pendidikan Islam: Studi atas Pemikiran Imam Zarkasyi. Sorong: Pustaka Rafana.

Wekke, I. S., \& Busri, M. (2016). Kepemimpinan Transformatif Pendidikan Islam: Gontor, Kemodernan, dan Pembelajaran Bahasa. Yogyakarta: Deepublish.

Wekke, I. S., Arif, B., Zubair, A., \& Wardi, M. (2019). The Role of Muhammadiyah Institution Towards Muslim Minority in West Papua. Jurnal Ilmiah Peuradeun, 7(1), 21-42.

Wekke, I. S., Yandra, A., \& Hamuddin, B. (2017). Learning Strategy in Class Management: A Reflection from Manado Case. In IOP Conference Series: Earth and Environmental Science (Vol. 97, No. 1, p. 012053). IOP Publishing. 